\title{
DELIMITATION AND CHARACTERISTICS OF NATURAL LANDSCAPES OF THE CHELMNO-DOBRZYŃ LAKELAND, URSZULEWO PLAIN AND THE NEIGHBOURING VISTULA AND DRWĘCA VALLEYS*
}

\author{
WŁADYS ŁAW NIEWIAROWSKI, RAFAŁ KOT \\ Geography Department, Nicholas Copernicus University, \\ Gagarina 9, 87-100 Torun, Poland; \\ E-mail: rafalkot $\lesssim$ umk.pl
}

\begin{abstract}
The study was based on the research completed by the authors. The research for the study was based on the use of a relatively broad selection of cartographic materials as well as scientific literature. The characteristics of 17 kinds $^{1}$ of natural landscapes and 31 variations of landscape of the Chelmno-Dobrayn Lakeland, Urszulewo Plain and the neighbouring Vistula and Drwęca Valleys were described. The origins of the terrains provided the main criteria used for identifying the kinds of landscapes. A relationship to the appropriate sort of natural landscapes (glacial, glacioaquatic, aeolian, depression, river and channel valley), and the morphology and hypsometry of the land reliefs (flat plains, undulated plains, hills, ridges, high slopes) determined the terrain origin. When identifying the different variations of natural landscape, the following were of major importance: the land relief (defined as the kinds of landscape), and lithology of the surface deposits, and land use (forests, arable land, meadows and pastures). Urban areas and large excavations were described separately. Similar distinctions of kinds and variations of landscape used by other authors, are noted elsewhere.
\end{abstract}

Key words: typology and evolution of natural landscapes, kinds and variations of landscape, physico-geographical mesoregions

\section{INTRODUCTION}

"Landscape" is an ambiguous concept, since it is defined differently in different scientific disciplines (for example, in botany, landscape ecology and landscape architecture). In landscape ecology, this is a heterogeneous area of land formed from mutually-interlinked ecosystems (Forman and Godron

\footnotetext{
"A slightly modified version of the article published in Polish in Przeglad Geograficzny. (Niewiarowski, Kot 2010)

${ }^{1}$ Authors' comment: Where the terms used for various levels of organisation of the natural landscape are concerned, the authors of this paper have followed the
}

1986). A. Richling and J. Solon (1996) defined landscape as a complete if heterogeneous whole, functioning in accordance with the laws of nature, imbued with a capacity for self-regulation and characterised by

\footnotetext{
English translation by Richling, A. (1984, p. 30) closely, making use of the terms class, sort, kind and variation. In both the Polish and foreign literature there is a high level of complexity to be observed as regards the use of terms for landscape units of similar taxonomic rank (or dimension). The translation of the said terms into English is also problematic. To that end, with a view to the specificity of the presented division being made more understandable to a foreign reader, it is possible to suggest an alternative translation for the natural landscape units, i.e. class, seria, type, sub-type.
} 
a certain individuality. There are also differences in the understanding of the concept of "landscape" in foreign geographical literature. In the post-war Polish geographic literature, the concept of natural landscape most widely used was that defined in the work of J. Kondracki and his student A. Richling (Kondracki 1960, 1981; Kondracki and Richling 1983; Richling 1972, 1992). The concept of landscape and its typological classification have been modified in the works of Richling and Kondracki numerous times. Kondracki (1960) states that Polish divisions of natural regions are based on differences in geological structure, surface relief of the earth, and the hydrographic, meteorological and geobotanical relations. He identifies the Polish landscape types based on the similarities of the above mentioned geographical environment components. In his work, Kondracki does not yet strictly define the term "landscape". Instead he assumes that Polish geographers understand this term in a general sense as a physiognomical type of a geographical complex. Kondracki also presents a Polish natural landscape classification scheme. He breaks his scheme down into: 2 classes (the 1st - landscape of lowlands and plateaus, and the 2nd - mountains), 8 sorts and 29 variations. Kondracki divided the lowland landscapes into:

1. Early-post glacial landscapes (with three variations):

a) the moraine plains

b) the hummock, lake district landscape

c) the sandur landscape;

2. Accumulative valleys and plains (also three variations):

a) the flood valley landscape,

b) the dune terrace landscape

c) the river-lake landscape.

It should be emphasized, that Kondracki views the main feature of the diversity of natural landscapes to be the relief of the territory which is inherent in the bedrock. In his textbook from 1981 (Kondracki 1981, p. 230), he states that natural landscape is "land with a specific type of structure, which consists of an interconnected surface sculpture with the following: its lithologi- cal composition, water, climate, biocenotic and soil relations as well as the human imprints modifying natural conditions. In this sense, the natural landscape does not mean "primary". Instead, the definition includes natural phenomena, meaning the areas of farm, forest and water holdings. The definition does not include large urban and industrial agglomerations which together with natural landscapes create the concept of the geographical environment". However, in the article A. Richling and Kondracki wrote together (Kondracki and Richling 1983), they acknowledge that landscape is:

1) part of the epigeosphere representing the spatially multiple geocomplexes have a specific structure and internal relations, and landscapes usually are considered in terms of a typological and hierarchical system.

2) the Earth's external surface seen from a particular place.

In his textbook, J. Kondracki (1981) gives a slightly different typological classification of the landscape, distinguishing 3 classes (lowland, upland and mountain landscapes). Kondracki repeats the same sorts of landscape for lowland areas, but instead of variation he uses the term 'kind'. The reason for the change is that "variation of the landscape' is a more general, all-encompassing term. 'Variation of the landscape' can be used to identify the 'types of terrain', or used to identify a set of genetically related microchores. In this classification, Kondracki skips the lake-river type classification. A. Richling (1972) dealt with the problem of naming repetitive typological units of the landscape from the Great Masurian Lakes region (an area of $1,675 \mathrm{~km}^{2}$ ), by dividing the area into 6 variations of landscape. These variations are: the marginal, floor-moraine, fluvioglacial, limnoglacial, kettle (together with other glaciogenic depressions) and anthropogenic forms, and 19 types of morpholithogenetic microchores. In our study, we conclude that variation of landscape is the smallest typological complex unit and fits the "type of terrain" distinguished in the physio-geographical division of regions. The 
lithology of the substrate and the morphogenetic models of the terrain play a leading role when distinguishing between the different physio-geographical regions. In the article from 1984, Richling states that on the basis of his own research and data from other universities, he developed a new map of Polish landscape models. The scale was 1: 500000 (first time published), and was later printed in Richling's manual (Richling 1992) at a much-reduced, unspecified scale. Later, Richling and A. Dąbrowski (Richling and Dąbrowski 1995) drew up a map with a scale of 1:1 500 000. Richling also states that while making this map, the substrates lithology and land use were determined and taken into account, to distinguish variations across the Polish landscape. So far, 120 variations of landscape have been distinguished by various researchers. Due to the scale of the published maps, all of these variations are not included. Nowadays, the typology on the published Polish natural landscape maps is far from what the previous typology was.

It is not necessary to discuss here all the types of Polish landscapes which have been identified. We will only mention the changes in the Polish lowlands within the last (Vistulian) glaciation (Fig. 1). Comments to these and other distinctions are included later in the article.

The above typology of natural landscape on the area of the last glaciation, is not the only typology. R. Galon (1984) published the article: "Types of Natural Landscapes and Geographical Regions", in which he describes 10 landscape variations featured in the former Torun province. R. Galon distinguishes the landscapes mainly based on the relief, type of surface sediments, forest cover and climate, lakes, and soil. He emphasizes, however, that variations of landscape are mainly distinguished by the landforms, lithology of surface layers, and land use. The most important of these features is the forest vegetation. Galon, unfortunately, does not present these variations on the map and does not use other authors designations. His variations are given in these brief forms, they are: forestless clay plateau plains; forestless clay, sometimes undulated plateau plains; forestless clay undulated plateau plains with rare hummocks; the forested channel-lake landscape; clustered together moraine and kame hillocks, partially forested; bigger terrain steps occurring on the border between moraine plateau and river valleys and deep channels; sandur and terrace-valley sandy plains usually forested; sandur and terrace-valley sandy plains with dunes, usually forested; river, usually sandy and partially forested plains with lower river terraces, the agricultural-forest landscape; flat, sometimes boggy valley floors, and the floor-valley landscape.

Recently, a publication by A. Richling et al. (2005) was released about landscape typology and the physio-geographical regionalization for the area of the Plock Municipal-Industrial Complex and the Plock Environmental Hazard Area (an area of $3,600 \mathrm{~km}^{2}$ ). The composition of this area includes the southern part of the Dobrzyn Lakeland and part of the Plock Basin. In this area, Richling et al. distinguish four kinds of landscape (plains, undulated and hummock, hillock, and slope). Instead of introducing a smallest unit of landscape within the (kinds of) variations of landscape, they introduce a new distinction: "type of landscape". They define 'type' as a unit based on the lithological characteristics of surface forms and morphological characteristics, i.e. the relief. They also conclude that current land use can be described as a separate category called "variants of the landscape". This new category does not have much in common with certain types of landscape. As a result, Richling et al. distinguished 14 types and 7 variants of the landscape. Some examples of the types of landscape are: the plains of the valley floors and the depressions with peat and organic alluvion; the plains of plateaus with clay and loam; undulated and hummock plateaus with clays; the steep sand-gravel slopes. Examples of variants of landscape include: agricultural landscape, forest landscape, agricultural-meadow landscape, and wastelands. 


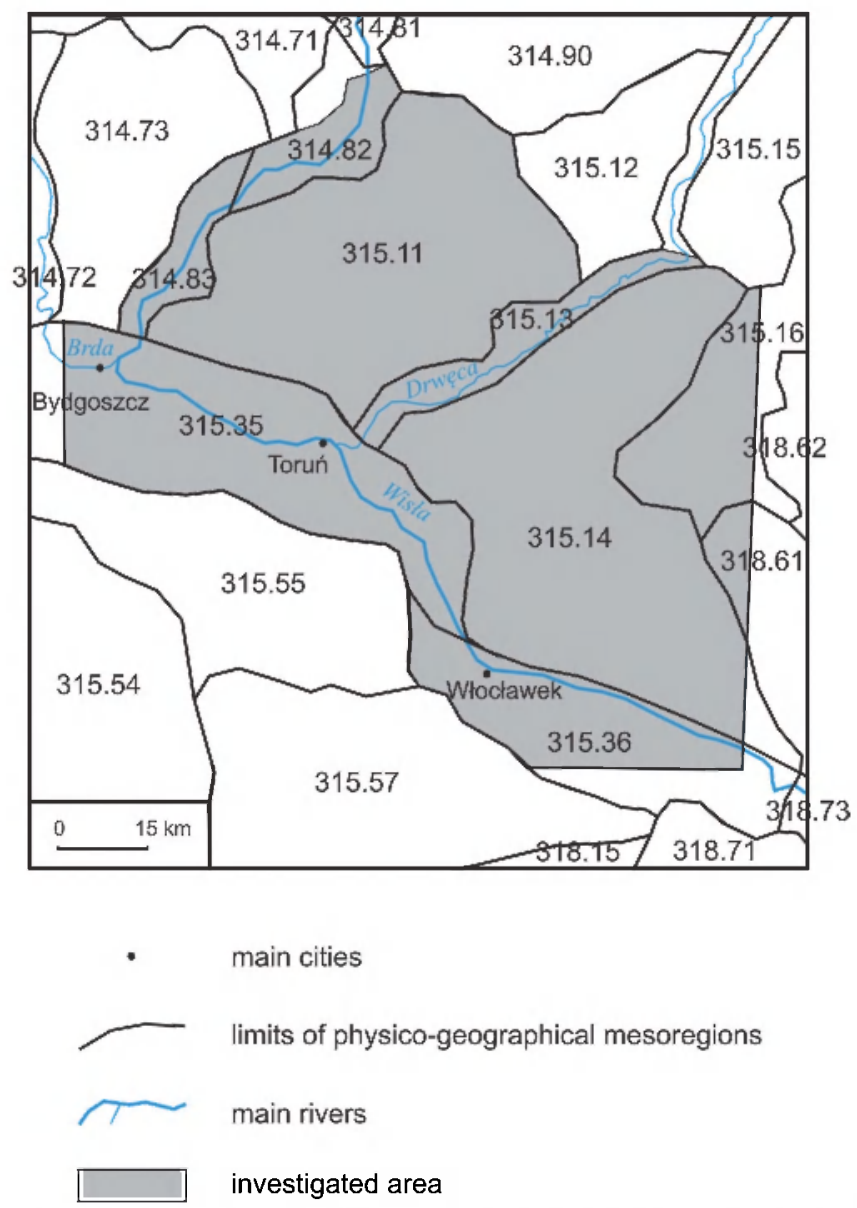

Figure 1. Location of the examined area against the background of physico-geographical regions after J. Kondracki (1998)

Physico-geographical mesoregions: 314.71 Tuchola Forests, 314.72 Brda Valley, 314.73 Świecie Plateau, 314.81 Kwidzyn Valley, 314.82 Grudziądz Basin, 314.83 Fordon Valley, 314.90 Ilawa Lakeland, 315.11 Chełmno Lakeland, 315.12 Brodnica Lakeland, 315.13 Drwęca Valley, 315.14 Dobrzyń Lakeland, 315.15 Lubawa Elevation, 315.16 Urszulewo Plain, 315.35 Toruń Basin, 315.36 Plock Basin, 315.54 Gniezno Lakeland, 315.55 Inowroclaw Plain, 315.57 Kujawy Lakeland, 318.15 Klodawa Plateau, 318.61 Plońsk Plateau, 318.62 Raciąż Plain, 318.71 Kutno Plain, 318.73 Warszawa Basin

The above descriptions clearly show that typological classifications of the landscape for the area of the last glaciation, which have been in use up till now, are still an open question. This applies particularly to kinds and variations of landscape, which have rarely been examined and characterized. Various criteria have been used for making the distinction. In response to R. Galon's (1984) publication, we decided that: the relief, the lithology of the surface forms, and the land use (arable lands, green lands and forest) play a key role in the identification of the landscape variations of the Polish Lowlands. The land is the main criterion for distinguishing the variations of the landscape and is particularly important when distinguishing sandurs and overflood terraces, on which the terrain and sediment lithology are similar As mentioned above, 
the criterion used to describe the relief of the terrain and lithology of the surface forms are adopted from A. Richling et al. (2005) who distinguish "types of landscape" which are probably equivalent to the "variations of landscape." Therefore, we consider our paper a contribution to the discussion about the kinds and variations of landscape in the Polish lowlands.

It is important to point out, that methods for distinguishing types of landscape in other countries are often very different (see Solon 2008). Typologies of landscapes in parts or all of Europe have also been devised in recent years (e.g. Mücher et al. 2003, Mucher et al. 2010), though obviously those produced for such large areas are of a generalized nature, making them unsuitable for comparison with the more detailed works elaborated for smaller areas.

\section{THE STUDY AREA}

The following physiogeographical mesoregions are highlighted by J. Kondracki (1998) and used in the study area. These regions include: Chelmno and Dobrzyń Lakelands (without the small section which is west from Plock), the Urszulewo Plain (without the northern part), most of the Plock and Torun Basin (without a western part of the Torun Basin, the area west of Bydgoszcz, the Fordon Valley, most of the Grudziądz Basin, and the bottom part of the Drwęca Valley (Fig. 1). The study area encompasses the maximum range of the last glaciation of the Poznań phase, the Kujawy-Dobrzyń subphase, and the Krajna-Wąbrzeźno subphase. To the east, there is a small part of the area of the Srodkowopolskie glacier that is not included in this article. Specific features of the study area did include: its relatively low position above sea level, the enormous domination of plains, and the slight differences in relative heights. The altitude of the Dobrzyń and Chełmno Lakeland is from $80-100 \mathrm{~m}$ to about $130-150 \mathrm{~m}$ above sea level. The Urszulewo Plain varies between 110 and $150 \mathrm{~m}$ above sea level. The altitude of the Vistula Valley, on the other hand, ranged from 80-82 to $19 \mathrm{~m}$ above sea level, and in the Drwęca Valley, from about 100 to $36 \mathrm{~m}$ above sea level. The relative heights of the prevailing area do not exceed more than 25 $30 \mathrm{~m}$. Yet, on the slopes of the Vistula and Drwęca Valleys and in deep tunnel valleys, the relative heights reach a maximum of $40-$ $60 \mathrm{~m}$. Despite the dominance of plains, these areas do not lack variety. Actually, it is quite the opposite - there is a great diversity of forms with different structures and origins.

\section{METHODS OF ELABORATION}

The 1: 200000 map scale shows the ranges of the individual kinds and variations of landscapes (Fig. 2). The primary method used for marking these landscape features are detailed-thematical maps (1: 50 000) as well as reference-thematical maps (1: 200 000 ). These maps mainly concern geomorphology and geology structure of kinds and variations of landscape. In the case of an absence of maps, scientific literature and information about the area based on experience were used to differentiate between the different kinds and variations of landscapes. Available information about particular components of the natural environment is various. The best documented data concern the relief and the lithology of the surface forms. There are 9 sheets of geomorphological maps at a scale of 1: 50000 , and 1 morphogenetic map at approximately the scale of 1:150 000 for most of the Chelmno Lakeland (Niewiarowski 1959). From available sources, there is also a fairly developed geomorphological map at a scale of 1: 200000 , depicting the area of the former province of Toruń (Podgórski 1996). For àreass not covered on this map, W. Niewiarowski developed a new geomorphologic map at a scale of 1: 200000 , for the purposes of this article. For the study, there have already been published 25 sheets of detailed geological maps at a scale of 1: 50000 . Since these 1:50 000 scale maps do not include the whole area, geological maps at scale of 1: 200000 
were also used. Lithological separation, especially on the detailed geological maps, form a mosaic of contours (particularly on the moraine plateau). These contours could not be included on a 1: 200000 scale map of landscape variations (Fig. 2). Generalization was thus necessary, and this also applied to maps of soils. The description of soil maps was based on the recent work by R. Bednarek and Z. Prusinkiewicz (2001) and R. Bednarek and M. Jankowski (2006). There are no detailed maps of the vegetation of the area. This prevented defining the current ranges of individual plant communities on the map (Fig. 2). There are, however, a number of descriptive studies, such as K. Kępczyniski's $(1965,1973)$, M. Rejewski's (1971) and M. Ceynowy-Gieldon's (1984). These studies characterize the individual plant communities. According to L. Rutkowski (2006), the vegetation of meadow and pasture data contained in these studies work have become obsolete. Melioration of wetlands, and new plants which were planted in what was previously the wetlands, are the reason the data became obsolete. Groups of forests, however, did not undergo this process so the information is current.

The land use map was created by collecting the sections of the second level of Corine Land Cover $2000^{2}$. Six types of land use were eventually obtained: built-up areas, agricultural land, meadows and pastures, forests, large excavations, and water. All these land use types are presented in the map (Fig. 2). It can be generally assumed, that meadows are areas that have shallow $(0-2 \mathrm{~m})$ groundwater retention. Pastures occur not only in shallow groundwater retention areas but also on areas that are not suitable for agricultural use. Hillside drops and flat areas with very poor soil make land agriculturally undesirable.

The map of landscape variations (Fig. 2) was made up of eight double topographic map sheets at a scale of 1:100000 "in the 1942 system": Brodnica N-34-99/100 from 2006,

${ }^{2}<$ www.eea.europa.eu/themes/landuse/clc-download $>$
Bydgoszcz N-34-97/98 from 1996, Grudziądz $\mathrm{N}-34-85 / 86$ from 2004, Ilawa N-34-87/88 from 2000, Inowrocław N-34-109/110 from 1996, Płock-Włocławek N-34-123/124 from 1997, Radziejów N-34-121/122 from 1996, and Sierpc N-34-111/112 from 1994, published by the Military Cartographic Department. Sheets of topographic maps, geomorphological maps, and Geological Poland Maps at a scale of 1: 200000 (Brodnica, Grudziądz, Iława, Konin, Torun, Płock) were rectificated in ArcGIS and brought to a "1942" coordinate system of geographical locations. Topographic maps were used for digitization of the main watercourses. These watercourses signified boundaries of relief units, based on thematic maps.

\section{THE MAIN STAGES IN THE FORMATION OF THE NATURAL LANDSCAPE IN THE STUDY AREA}

The landscape of the designated area of our study was formed 18 thousand years ago. The oldest landscapes i.e. glacial, fluvioglacial, and ice marginal terraces (XI, X) of the Drwęca River and Vistula River started to form during vistulian from about 18 to $15 \mathrm{ka}$ BP. These landscapes underwent changes during the Late Glacial Era $(14.0-10.25 \mathrm{ka}$ $\left.\mathrm{BP}^{3}\right)$, mainly when the climate started to grow warmer (mainly during Allerød 11.8 $10.9 \mathrm{ka} \mathrm{BP}$, when birch-pine forests already occurred). These landscapes also underwent changes because of the melting of the buried, dead glacial ice (also gydrogenic origin). Tunnel valleys, in turn, were uncovered, and melt-depressions filled with water eventually forming lakes. In this way, a lake district landscape was created. Small-sized lakes began to disappear due to the accumulation of mineral and organic sediments. Such a transformation had already started happening in the Late Glacial Period, but mainly in the Holocene Epoch (10.25 ka BP to the present). The disappearance of small-sized lakes largely caused peat-formed biogenic

\footnotetext{
${ }^{3}$ Years according to L. Starkel $(1997,1999)$
} 
plains. Nowadays, lakes make up only $33 \%$ of the initial area (Kalinowska 1961). On the study, area the lakes take up approximately $1.3 \%$ of the general area.

A landscape of small river valleys started to form in the late glacial period. A new stage of channel valleys also started forming in this late period. Within those channel valleys and valleys of the Vistula, Drwęca and Right Skrwa Rivers (for which we still use the name Skrwa), a overflood terrace landscape was forming. During the cold phases of the late glacial period; in the Older (12.1-11.8 ka BP) and Younger (10.9-10.25 ka BP) Dryas, a acolian landscape took shape in the Vistula Valley and in the adjacent areas. This aeolian landscape was later concealed with forest cover. In the cold phases of the late glacial period when permafrost was present, periglacial valleys were created on the slopes of the Vistula and Drwęca Valleys.

Significant changes occurred in the existing landscape during the Holocene Epoch. A huge variety in the floral vegetation also took place, floodplain landscapes in the valleys appeared. These differences depended on the formation of new, varied types of soils and on the formation of biogenic plains. In the Holocene Epoch, humans and their farming habits made their appearance, significantly affecting the landscape transformation. In the study area, humans had already appeared in the Younger Dryas, but their activity affecting the primary landscape is dated from the Neolithic Era (about 6.0-6.5 ka BP). In this region, the Neolithic Era is counted from the time people migrated to this area and started planting their own food. One of the most significant changes was the practice of clearcutting. In the older archeological periods, changes in the natural environment were relatively small. Bigger, important changes are dated from the Early Middle Ages. During the Middle Ages, the practice of consistent clearcutting had begun. Farming tools and farming itself had begun to improve significantly. In the XVI century, especially in the Chelmno Lakeland, the clear-cut area looked similar to the present state. Nowadays, the Chelmno Lakeland and Kujawy area are the least forested areas in the whole country. For example, in the Chełmno district, forests make up only $6 \%$ of the general area, and in the Wąbrzeźno district, forests make up only $8 \%$ of the general area.

On the whole area, primary forests underwent almost total destruction. Those forests whose composition is close to the original one, remain today only in places which are difficult to access. In these places, nature reserves have been created. The reserves occur in narrow and deep valley canyons (Osa, Brynica), in arroyos (Plutowo), on some valley slopes and occasionally in small patches on the moraine plateaus.

In new forest tree stands, pine trees dominate. The pine trees are about $80 \%$ of the whole tree stand area. After cutting and burning down the forests, a new kind of farm vegetation accompanied by weeds appeared. Thus, a farm landscape was created. After people meliorated and dried the swamps and marshes, and limited the flood area, some new kinds of meadow and pasture plants were introduced (meadow landscape). As a result of the clearcutting and field cultivation, an increase in anthropogenic denudation occurred. This denudation caused reduction of the $0.8-1.0 \mathrm{~m}$ undulated moraines and drumlin mounds. In the lower parts of the slopes and in the neighboring depressions, denudation covers formed with a maximum thickness $1.5 \mathrm{~m}$ (Sinkiewicz 1998). As an effect of human farming activity, new anthropogenic forms arose (holes, railway and road paths, embankments, canals, and fortifications). These anthropogenic forms already make up $6,97 \%$ of what was the former province of Toruń (Podgórski 1996). Similàr anthropogenic changes occurred in soils, for example: diluvial soils on the denudation covers, muck soils on the dried moors, and anthropogenic soils in the cities. Changes in the natural water systems were based mainly on the processes of drying the marshes and swamps, regulating the rivers, creating embankments etc. 


\section{DETAILED CHARACTERISTICS OF KINDS AND VARIATIONS OF NATURAL LANDSCAPES}

\section{INTRODUCTORY REMARKS}

The sorts and kinds of the mentioned natural landscapes (Table 2, Fig. 2) were used according to A. Richling's (1992) typology of natural landscape (Table 1). The criteria for distinguishing the landscapes are the same, but there are differences in the typologies. In Richling's typology, the term "fluvioglacial landscape" is used. As the name suggests, the fluvioglacial landscape includes forms and sediments created by glacial runoff. These forms and sediments are: sandy and gravel sandar, the highest ice-marginal valley terraces, and some types of kames and eskers. In addition, structures and sediments that were formed in glacial lakes (for example, limno-glacial kames) occurred in the areas that were previously glaciated and mainly in isolated still water lakes. Such still water lakes were built with silt and loam or with fine sand. A. Richling (1972) distinguishes between these kinds of forms and sediments which cover large areas, especially in Northern Poland; on the Pyrzyce and Warmia Plain, and on the Sępopol Lowland and many other regions including the area we are discussing in this article. The forms and sediments did not, however, reflect Richling's (1992) typology. In geomorphology and geology of the Quaternary Period, the term "glacioaquatic sediments and forms" is used for defining the fluvioglacial and limno-glacial sediments and forms. For this reason, we prefer to use the term glacioaquatic landscape instead of fluvioglacial landscape.

\section{AUTHORS' OWN ELABORATION}

In our opinion, there is also a need to use the term 'channel valley' which is a separate sort of landscape within the valleys in the area of the last glaciation. The reasons are given in full, in a later section of the paper.

Because of the lack of detail, on geomorphological maps, flat and undulated plains were not singled out at all nor were ridge forms in Richling's typology (Table 1). We assumed, according to The Detailed Geomorphological Map of the Polish Lowlands, scale 1: 50000 (1962), that flat plains are plains with: relative heights up to $2 \mathrm{~m}$, and $0-2^{\circ}$ drops $(0-3.5 \%)$. The undulated plains are plains with relative heights of $2-5 \mathrm{~m}$, with $2-5^{\circ}$ drops $(3.5-8.75 \%)$. The flat plains were singled out because there is no mechanical water denudation (no soil water denudation). On the flat plains, it should be noted that there is a lack of surface drainage but floods can take place. Mainly rich black dirt and bog soil can be found on these kinds of plains. On the data which existed (except for the sandur forest area) for the study area, we were able to

Table 1. Types of natural landscapes on the area of Vistulian Glaciation in Poland based on A. Richling's classification (1992)

\begin{tabular}{lll}
\hline Classes & Sorts & Kinds \\
\hline Lowland landscapes & glacial & $\begin{array}{l}\text { flat and undulated } \\
\text { hummocky } \\
\text { hillocky }\end{array}$ \\
& fluvioglacial & flat and undulated \\
& acolian & hummocky and hillocky \\
\hline Valley and immersion landscapes & flood valley floors- accumulative & flood plains \\
& $\begin{array}{l}\text { flood terraces-accumulative } \\
\text { deltaic-accumulative } \\
\text { bog plains }\end{array}$ & terrace plains \\
\hline
\end{tabular}


Table 2. Types of natural landscapes

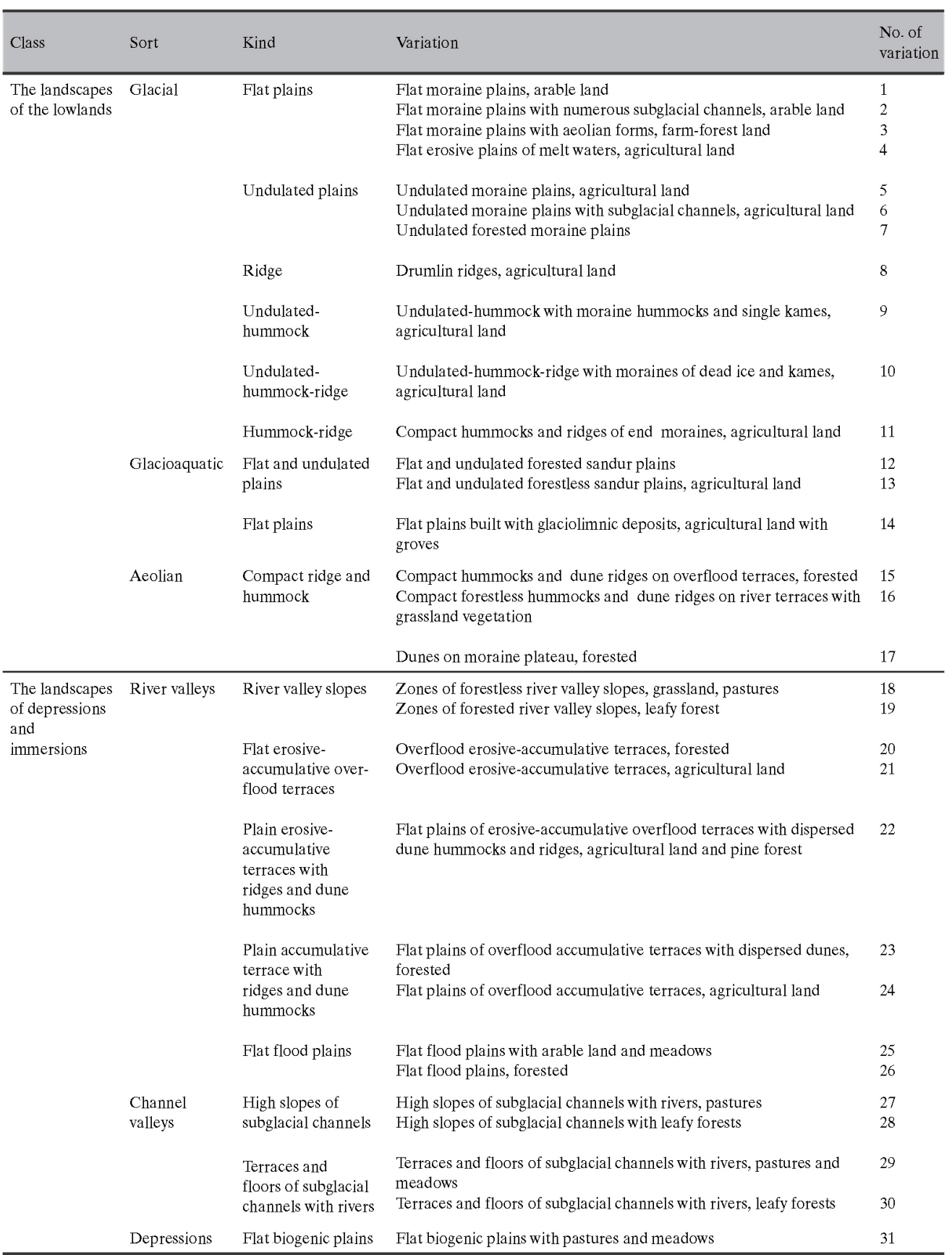




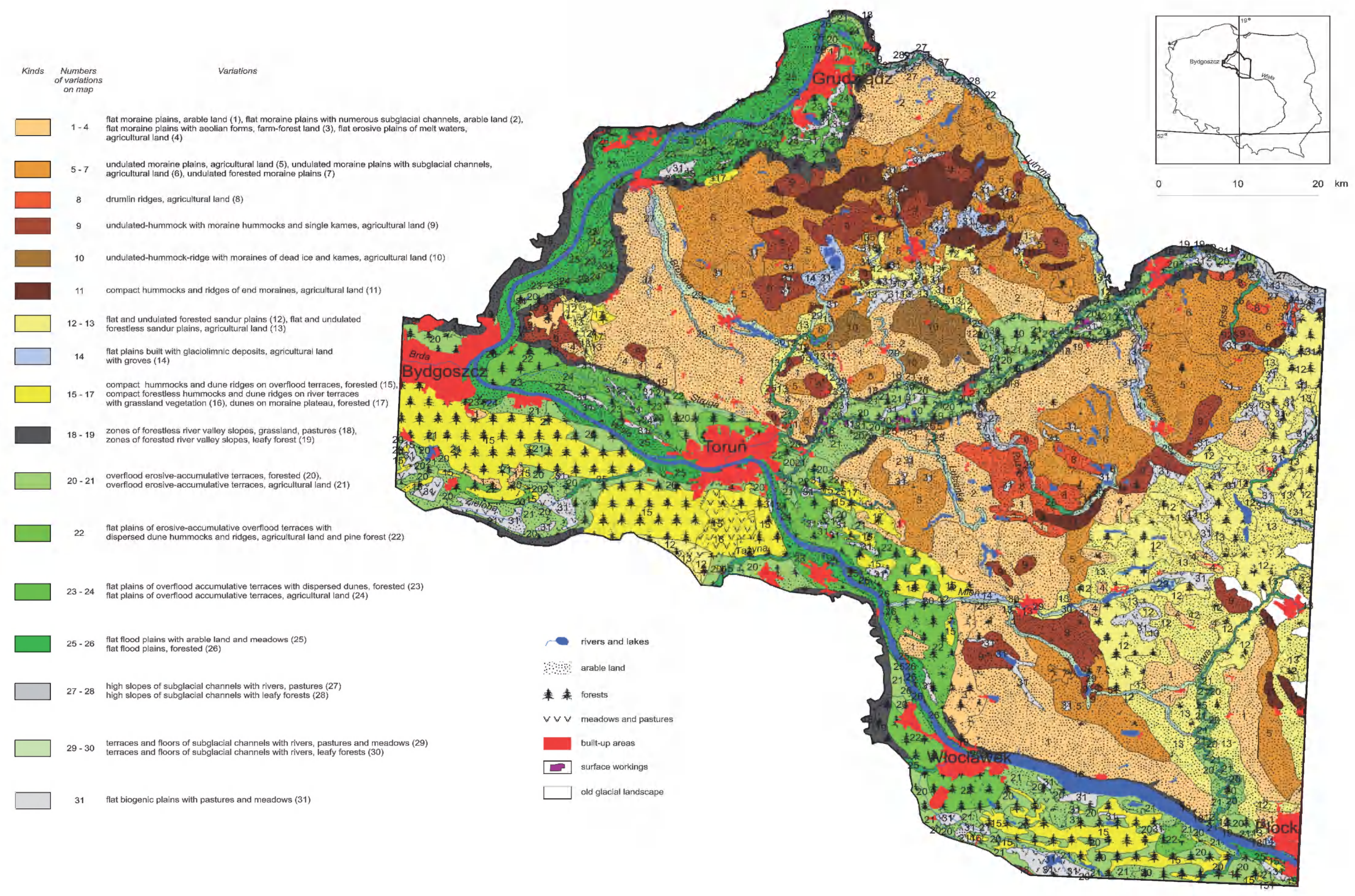



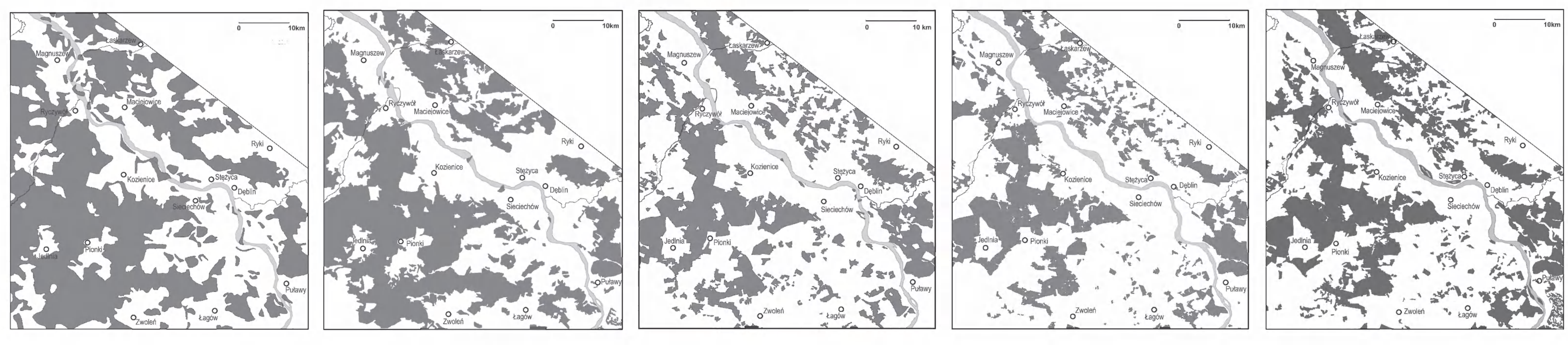
make the distinction between flat plains and other plains. Along with many other authors, we stated the following, more reliable points which differ from those in the manual about the Polish lowlands: relative heights for hummocks 5-20 m, drops differed; rarely exceeding over $15^{\circ}$ (about $27 \%$ ). For hills, the relative heights are over $20 \mathrm{~m}$ and also different drops $\left(5-20^{\circ}\right)$. It is recommended, that degree and percentage of the drop be included because according to $\mathrm{S}$. Borowiec (1968), on terrains with $20-30 \%\left(11.3-16.6^{\circ}\right)$ drops, farming is still possible along the furrows of the slope. Such farming conditions can be seen on the study area. The use of combines is possible only on terrains with a smaller drop.

It was not necessary to include the results for ridges since there are almost only ridges in the drumlin landscape. A similar tendency occurs in the aeolian landscape, where there are straight dune ridges and parabolic dune ridges. In the terminal moraine landscape, there sometimes occur large moraine ridges several $\mathrm{km}$ long and several meters high. These ridges cannot be counted as hummocks and hillocks and small or big hills.

As mentioned above, the variations of landscape which we differentiate, relate in general to R. Galon's (1984) landscape distinctions. Our distinctions are, however, more numerous, more varied, better documented, and shown on a map (Fig. 2). In kinds and variations of landscapes, we also note the landscápes of the high slopes of the river and channel valleys. In addition to the kinds and variations of landscape, Figure 2 also shows built-up areas (urban and industrial), bigger excavations, fragments of the old-glacial landscape, rivers longer than $15 \mathrm{~km}$ and bigger lakes, without giving the characteristics of these areas in the description.

\section{LANDSCAPES OF THE LOWLANDS}

\section{Kinds and variations of the glacial landscape}

\section{The landscape of flat moraine plains}

There are 4 variations of landscape indicated within this kind.
1- The landscape of flat moraine plains, arahle land

This landscape is characterized by $0-2 \mathrm{~m}$ relative heights, $0-2^{\circ}$ drops, sandy-gravel clay heap, and sometimes a clay-sandy cover (ablation clay) or heap clay sands. On these formations, mainly fawn and fawn-glian soils (LUVISOLS, STAGNIC LUVISOLS IUSS WORKING GROUP WRB 2007) were created in the shallow standing rain water, and patches of rich black soil (MOLLIC GLEYSOLS IUSS WORKING GROUP WRB 2007) were present. The biggest area of flat moraine plains primarily occurred in the south of the Chelmno area (see Fig. 2). Melt depressions embellish this landscape with locally wet biogenic sediment and ponds, mainly of anthropogenic origin. The convenient relief and top-quality soil in this region are the reasons there have been no forests on these plains for a long time. These plains have been reserved for agricultural purposes. Sometimes, meadows and pastures can be found on the bottoms of the wet low parts.

2- The landscape of flat moraine plains cut with many subglacial channels, local ribbon lakes or peat plains These features take place when the lakes become overgrown by plants

The rest of the flat moraine plains' environmental characteristics and their use are the same as in type 1 (see Fig. 2)

3- The landscape of the flat moraine plain with diversified aeolian forms

This variation of landscape occurs in the south-western part of the Dobrzyn Lakeland, next to the Vistula Valley, north from the city of Wloclawek up to Mien Valley (Fig. 2). In this area, there are mostly sandy clay on which aeolian covers developed as well as longer dune forms. Acolian forms are not yet well researched. The main element of the landscape is, however, the moraine plain. The soils here are diverse-rusty soils, BRUNIC ARENOSOLS and LUVISOLS (IUSS WORKING GROUP WRB 2007) are on the moraine plain, and PODZOLS (IUSS WORKING GROUP WRB 2007) on the dunes. Land use is also diverse because the aeolian forms grow within the forests, 
and the moraine plain is used for farming. A similar landscape but with wooded kemes and small dunes, can be seen in the Dąbrowa Chełmińska area.

4- The landscape of flat erosive plains of melt water

Plains made of washed out fallen clay make up these landscapes. This clay appears on the surface or is covered with a non-continuous, thin layer of sandy-gravel formations made of stone. These plains occur in: the regions of Lubianka and Lążyn, in the south part of the Struga Toruńska sandur trail, on the Urszulewo Plain, within the Skrwa sandur, and on the upper terrace of the Vistula River in the narrow part between the Plock and Toruń Basin (Wiśniewski 1976). These kinds of plains also have no forests and are used for farming purposes.

\section{Landscapes of the undulated moraine plains}

In this kind, 3 variations of landscape have been distinguished.

5- The landscape of the undulated moraine plains

This landscape has plains with relative heights reaching 2 to $5 \mathrm{~m}$ and drops usually from 2 to $5^{\circ}$. They are largely made up of fractionally diverse, falling clays as well as falling clay, sand, and gravel. The main types of soil located on these plains are luvisols (EPICUTANIC LUVISOLS IUSS WORKING GROUP WRB 2007). This soil is chiefly in the parts which have been used for farming purposes over a long period of time. Also, deluvial soils (COLLUVIC REGOSOLS IUSS WORKING GROUP WRB 2007) sometimes occur on denudation covers. On the wet parts of depressions, where lakes previously existed, there are organic soils which are mainly peat. After melioration and drying, muck soil begins to form on these soils (HISTOSOLS IUSS WORKING GROUP WRB 2007). These kinds of depressions are partially used for farming, but it is meadows and pastures that mainly occur there. The number of kettle depressions (kettle holes) is usually bigger here than on flat moraine plains, and lakes are also present. Undulated moraine plains are common, except in rare cases when the plains are used as farm land. The undulated moraine plains occur in the same area as the flat moraine plains (Fig. 2) making the borders between them blurred.

6- The landscape of the undulated moraine plains with many subglacial channels

Except for the channels, the features and the use of the natural environment are similar to variation 5 . The landscape of the undulated moraine plains with many fluvioglacial channels, occurs next to variation 5 , and in the Dobrzyń Lakeland, and on the north-west part of the Chelmno Lakeland.

7- The landscape of the undulated forested moraine plains with the same morphological and lithological features as the previous variation

On these plains, small patches of dry-ground forest types remain north-west of the town of Wąbrzeźno, next to the village Wronie. This tall dry-ground forest patch contains oak, hornbeam, linden and beech. Part of the Pomorskie Beech Reserve also belongs to this forest. Smaller patches of leafy forest occur in the area of the village of Plachoty, and near the Dobrzyń Lakeland in a village called Orłowo.

\section{Rigde-drumlin landscape}

There is only 1 variation in this landscape.

\section{8- Ridge-drumlin landscape}

This variation of landscape is characterized with a unique relief not seen on any other early post-glacial landscapes. The drumlins appear on the Dobrzyń Lakeland, on the periphery of the marginal forms of the Kujawy-Dobrzyń subphase, and in the depressions, and glacier channels. The ridge-drumlin landscape is seen in groups, on a few drumlin fields. The Zbójno drumlin field is the biggest. This field has $558 \mathrm{drum}$ lins (Nechay 1927; Olszewski 1994, 1997). In the area of the Zbójno drumlin field, there are a few more, quite little fields, located in the glácier ridges (Niewiárowski 1957; Liberacki 1969; Olszewski 1994, 1997). The drumlins are arranged in rows from $100 \mathrm{~m}$ 
to $2.13 \mathrm{~km}$ and formed as ridges. The width at the base of the ridge is $20-150 \mathrm{~m}$ and the height usually reaches $2-10 \mathrm{~m}$. The slope inclines vary, from a few to over a dozen degrees. The ridges are straight or slightly arched. They also have an uneven ridge surface, have an uneven bottom and are divided with depressions (these depressions have a width similar to the ridges). The ridges also have peatlands in which there used to be small lakes. In the northern part of the Lake area are 3 small drumlin fields (Koziary-138 drumlins, Górzno-59 drumlins and Miesiączkowo-65 drumlins). The drumlins in those 3 small drumlin fields are usually 50-200 long, 25-75 $\mathrm{m}$ wide, and 2-7 $\mathrm{m}$ high (Wysota 1994).

Almost all drumlins are built on a subglacial clay mound surface. Luvisoils (EPICUTANIC LUVISOLS IUSS WORKING GROUP WRB 2007), without at least the first level of soil, are on this surface. Only sometimes, on the Zbójno field, some forms create unsettled glaciotectonic sand compositions. On some drumlin fields (or next to them) limnoglacial kames or kame terraces appear. On large drumlin fields, many peat plains of different sizes still occur in river channels. All drumlins are used for farming purposes and have no forests. The depressions with organic soils (HISTOSOLS IUSS WORKING GROUP WRB 2007) are covered with pastures and meadows.

\section{Undulated-hummock moraine landscape - only one variation \\ 9- Undulated-hummock landscape with moraine hummocks and single kames}

The undulated moraine plain which has the same, or very similar characteristics as in variations 5-7, is a sizable part of this landscape. However, within this undulated moraine plain there are scattered hummocks. Sometimes, there are moraine ridges and a few kame hummocks in small groups. The relative height of these hummocks usually varies between 5 and $15 \mathrm{~m}$, and the drops from 5 to $15^{\circ}$. The hummocks also have different shapes. The surface of the hummocks and moraine ridges is usually covered with till (often the till has layers of sand-gravel sediments), or sand and clayey gravel. Kame hummocks are often made of sand and sometimes of sand with gravel. There are also many depressions (kettle holes) with wet biogenic sediments in the vicinity, and there are lakes on the kame hummocks. The hummocks and ridges, and the undulated moraine plain, have no forests and are also used for farming purposes. Only some steep hummocks are overgrown with pasture, and sometimes pastures and meadows are seen.

5. The undulated-hummock-ridge landscape with numerous kames and moraines of deadice

There is 1 variation.

10- The undulated-hummock-ridge landscape with numerous kames and moraines of dead ice

This is a classically formed landscape type and is seen in the area of Kowalewo (Chelmno Lakeland). There are kames in the form of hummocks, and these large mounds often have a flat surface (limnoglacial kames). Kames also occur in the form of ridges (up to $1 \mathrm{~km}$ long) or plateaus (82 ha). The relative heights of the kames reach $6-13 \mathrm{~m}$ with $4-15^{\circ}$ drops. Limnoglacial kames usually occur singly and are built of fine sand and loam. Glaciofluvial kames are built with sand, often with a mixture of loam and gravel. Relátively often, hummocks and dead ice moraine ridges can be seen. There also exist 3 esker ridges. The longest esker ridge is the Lisewo Esker $(4.9 \mathrm{~km})$. The dead ice moraines are usually in the form of groups of ridges and hummocks (4-12 $\mathrm{m}$ height, 5-10 ${ }^{\circ}$ drops). These moraines are arranged in a scattered way. Dead ice moraines can also be seen in the form of isolated and vast hummocks (up to $18 \mathrm{~m}$ high). These dead ice moraines are mainly built on the surface from ablation clays with layers of sand (they may be made of clay sands and gravel, though it happens very infrequently ). The above-mentioned forms occur in the undulated, clay moraine plain. Depression kettles and subglacial channels are often seen in this kind of landscape. Such 
kettles and channels have no forests, are used for farming purposes, and have pastures and meadows in the depressions on the floor of the channels. In some higher hummocks, forests of 2 kinds can be found. The first kind of forest is deciduous and it is probably the primary one. The second kind of forest is newly formed pine forest. The landscape variety in the area of Dąbrowa Chełmińska is similar.

\section{Hummock-ridge landscape}

This type of landscape has only 1 variation and appears on a few areas of various sizes.

11- The landscape of compact hummocks and ridges of end moraines

The biggest area where these forms appear is in the Chełmno Lakeland. This area extends $15-18 \mathrm{~km}$ to the west, and $8-15 \mathrm{~km}$ to the east. This landscape of compact hummocks and ridges of end moraines is part of the northern Wąbrzeźno end moraines. These moraines are formed as hummocks and numerous ridges both of which reach 5-20 $\mathrm{m}$. Only some moraines formed as hillocks reach $25 \mathrm{~m}$. Drops on the hummocks and ridges are various (usually $6-12^{\circ}$ ). The surface of the hummocks and ridges are mainly formed from clay sediments (clay, and only rarely sand and clay gravel). The strip of the southern Wąbrzeźno end moraines is quite small. These moraines measure $0.5-3.0 \mathrm{~km}$ and are also formed as hummocks and ridges, but are lower (5-12 $\mathrm{m}$ ) then the hummocks and ridges previously mentioned. The hummocks and ridges are made up of a similar lithology of sediments.

A compact strip of end moraines $(15 \mathrm{~km}$ long, 2-4 km wide) appear in the Dobrzyn Lakeland, in the area of the village of Chrostkowo. These moraines have a more diversified structure than the structure of the Wąbrzeźno moraines. In addition to the moraines with clay sediments, there are marginal ridges on the surface of the compact strip of end moraines. These ridges are built entirely of glaciofluvial sediments (sand and gravel). Similar marginal ridges are seen in the area of the village of Księte. There is a small region with end moraines - from the maximal range of the last ice sheet on the Plock Plateau. On the Plateau, in the area of the village of Gozdów, there is the ridge of a push moraine $5 \mathrm{~km}$ long and $25 \mathrm{~m}$ high (Kotarbiński 1966). In this landscape of compact hummocks and ridges of end moraines there are many drainless depression kettles (kettle holes) which have biogenic and denudation sediments on their floors. Also in this landscape, there are a few ribbon lakes. Despite the quite big hypsometric differentiation within the end moraine forms, the forms have drops which are suitable for farming purposes. This is why the end moraines are forestless and only sometimes pastures are seen. A small patch of an oak-hornbeam forest grows on the end moraine near Zuchowo (east from Lipno). There are pastures and meadows in the depressions.

\section{Kinds and variations of landscapes in the area of the glacioaquatic plains}

Flat and undulated glaciofluvial (sandur, outwash) plain landscapes and glaciolimnic landscapes are both part of the glacioaquatic plains type.

\section{The landscape of flat and undulated sandur plains}

As it has been mentioned earlier, there were not enough data to separate flat and undulated sandur plains, from the sandar which are covered with forests. In the study area, sandar are formed as if they were plains (like the Skrwa sandur also called the Wąbrzeźno sandur, Dobrzyń sandur in which there are 2-3 sandur layers), and in the form of relatively narrow $(0.5-2.0 \mathrm{~km})$, elongated sandur trails (the Chełmża sandur, the sandur of Struga Toruńska, the Mień sandur and the sandur on the Płock Plateau). In the Skrwa, Wąbrzeźno and partially in the Chełmża sandar, proximal parts of varied heights stand out, and flat sandur tapers are accentuated. These tapers are diversified with many kettle depressions of different depths which gives this part of the sandur the character of an undulated plain. The tapers have no significant boundary, and transform into flat plains which are dominant in the study area. These 
plains are diversified with less numerous but bigger kettle depressions. Many of the kettle depressions still retain ribbon lakes, for example, the Kamionki Lake in the Chełmża sandur or the large kettle Urszulewo Lake (293 ha and 2.8 depth). The proximal part of the sandur differs from the distal part of the sandur not only in its relief but also in the lithology and thickness of the sediments which can vary between a few and $20 \mathrm{~m}$. The sediments have various grains: sand-gravel with a dash of loam, or bulky gravel and stones. Further away from the proximal part, the sediments begun to be less thick, better sorted, and the fracture begins to be made up of more fine, to medium and fine sands. However, in the Skrwa, Struga Toruńska and Mien sandar (in places where the till bed was washed out and the sandur cover is only $0.5-1.5 \mathrm{~m}$ thick) there has been an increase in the size of the fracture (sand and gravel), but also the sorting was less precise.

On the sandar there are mainly rusty soils (BRUNIC ARENOSOLS IUSS WORKING GROUP WRB 2007) and sometimes podsolic soils (PODZOLS IUSS WORKING GROUP WRB 2007) (Bednarek and Prusinkiewicz 2001)

Within the sandur, 2 variations of landscape were distinguished.

12- The landscape of flat and undulated forested sandur plains

The biggest forest complex occurs in the northern part of the Skrwa sandur in the area of the Gorzno-Lidzbark Landscape Park. It is here, in the proximal part of the sandur, that vegetation is most varied. The main type of vegetation is a temperate coniferous forest with additions of oak, aspen, birch and willow. The main type of vegetation also includes leafy maple-linden forests with oak, maple and pine trees (Kępczyński et al. 1965). In the constantly wet depressions, in the area of overgrown lakes, and on the floors of the valleys, there are narrow strips of alder forests and riparian alder forests. In the southern part of the Gorzno-Lidzbark Landscape Park, and in the farther distant part of the sandur there is a dominance of fresh pine forests. The Wąbrzeźno sandur in the Joworze and Niedźwiedź area, is covered with a mixed forest with pine being the dominant tree. In this forest, oak, hornbeam, birch, and aspen also appear. The rest of the area, including the Chelmża sandur (except the floor of the channel in which there is a riparian forest) has been taken over by pine forest.

13- The landscape of flat and undulated forestless sandur plains

This landscape includes small patches of the Skrwa sandur terrain. On those patches, the the sandur sediments are quite thin. Under the sandur sediments is till. The till keeps the groundwater level low. The Struga Toruńska and Mień sandur look similar to the Skrwa sandur. Patches of the Wąbrzeźno sandur and the sandur trail on the foreground of the Plocka Plateau, end moraines are without forests. On the flat and undulated sandur plains which have no forests, rusty soils (BRUNIC ARENOSOLS IUSS WORKING GROUP WRB 2007) prevail. These soils are used for cultivating plants that need fertilization (rye, oats, lupins, potatoes and others). The floors of the depressions have organic soil HISTOSOLS IUSS WORKING GROUP WRB 2007) on which pastures and meadows can be found.

\section{The landscape of flat plains with glacio- limnic deposits \\ Only 1 variation was distinguished in this} kind.

14- The landscape of flat plains built with glaciolimnic deposits, agricultural land with groves

This kind of landscape occurs in small patches of the Chelmno Lakeland, in the plain of the end depression of Wieczno Lake, in the depression around Sitno Lake, and in the depression between the end moraine near the cities of Książki, Myśliwiec, Jaworze and Osieczko (Fig. 2). The biggest plain of Wieczno Lake is built with sand and clay layered with thin clay. At the riverbank, the plain is formed of fine sand containing calcium carbonate, however, the sand does not contain organic remains. On this plain there is a large peatland which formed after part of 
Wieczno Lake had become overgrown. The plain also contains small patches of alder forests, pasture and meadow vegetation, and small sections of agricultural land. In the area of the Sitno and Ksiązek Lakes, there are small plains whose deposits are part clay, part peat. On most of the plains there are meadows and no forests. Only a small part of the plains with glaciolimnic deposits is destined for farming purposes. A similar origin is shown on the map in the kame terraces of Brodnica, Rypienica and Mień subglacial channels (Fig.2)

\section{III.Aeolian landscapes}

In the study area, aeolian landscapes occur almost exclusively on the overflood terraces of the ice-marginal valley and the lower part of the Vistula Valley. Occasionally, the aeolian landscape is seen in the marginal parts of the moraine plateau. Aeolic forms include: irregularly shaped undulated aeolic covers (also called the low dunes), hummocks, and very often there are straight drumlin ridges with various heights, and parabolic ridge dunes. The drops of the dune forms are various and depend on the size and shape of the dune. This refers especially to the parabolic dunes, because their internal slopes show $3-20^{\circ}$ drops. The external slopes show $5-32^{\circ}$ drops. The dune forms usually occur in groups, making up dune fields. The biggest are the dune fields in the area of the Gostynin-Wloclawek Landscape Park in the Torun and Plock Basin. The lithological criterion does not differentiate the aeolian forms because almost all are made of sand (95\% of all sediments). The diameter of the sand grains are smaller that $0.5 \mathrm{~mm}$.

The vegetation and soils also do not vary much. Podsoils (PODSOLS IUSS WORKING GROUP WRB 2007) can be found almost everywhere on the dunes. In the depressions within the dunes and in the lower parts of the slopes (on the boundary with the marsh) podsolic glaysoils (GLEYIC PODSOLS IUSS WORKING GROUP WRB 2007) occur. On the forestless dunes, where right now a reduction process is tak- ing place, initial and regosols (REGOSOLS IUSS WORKING GROUP WRB 2007) occur. The dune areas are covered almost everywhere with pine forests. Pasture vegetation, psammophile grasslands or barren areas can be seen in the vicinity. The dunes vary not only in their heights but also in their density and in the amount of forests present.

\section{Compact aeolian ridge and hummock landscape}

In this kind, 3 variations are distinguished.

15- The variation of the compact forested hummocks and dune ridges on landscape of overflood terraces

In this complex, ridge dunes are most common. The ridge dunes include: long, straight ridges and ridges formed from connecting parts of the parabolic dunes, and parabolic and hummock dunes. The parabolic and hummock dunes were created partially through ridge dune blow-out. The biggest complexes of this type of landscape are on the left part of the upper terraces of the Torun Basin. According to W. Mrózek (1956), in the biggest complex there is a domination of dunes with a height of $10-25 \mathrm{~m}$. The highest dune reaches $44.7 \mathrm{~m}$. Although a bit smaller and shorter, these dunes are similar to the previous dune complexes in the Płock Basin. Even smaller (max. $20 \mathrm{~m}$ ) dunes that were formed in the Younger Dryas, occur on the lowest overflood accumulation terrace in the right part of the Torun and Grudziądz Basin.

16- The landscape of compact forestless hummocks and dune ridges on river terraces with grassland vegetation

The location is the Torun Basin on the area of the military training ground. This is a typical aeolian landscape because it is not covered with forests. In some places, after the soil has been devastated, a depression takes place.

17- The landscape of forested dunes on the moraine plateau

This landscape is the most typical landscape of all. It occurs in the area of Czernikowo on the Dobrzyń Lakeland. The dunes in this 
area were blown about $2 \mathrm{~km}$ from the Vistula Valley to the plateau. In the XVIII century, the area was de-forested and colonized. This caused the devastation of the podsols (PODSOLS IUSS WORKING GROUP WRB 2007) and also started the acolian processes. Depressions and deflationary covers were created (Churska and Kwiatkowska 1964). The aeolian processes and re-forestation stopped after 1960. A small patch of this landscape is found south of Unisław. The dunes by Unisław were formed on the plateau made of sand blowing off of the neighboring sandur. A small patch of this landscape can also be seen in the area of the village of Wielkie Łunawy where the dunes "enter" the Vistula Valley Plateau.

Scattered dunes are characterized as a terrace dune variation. This is because the terraces without dunes play the biggest role in the structure of the scattered dunes.

\section{THE LANDSCAPES OF VALLEYS AND DEPRESSIONS}

The previous typology referring to valleys is, in our opinion, too general. Only 4 sorts and 2 kinds of landscape are distinguished (Fig. 1). This typology does not include the fact that river valleys vary not only under genetic and morphological circumstances but they also vary in landscapes. It should also be emphasized, that not all valleys have overflood terraces. V-shaped, ravine and channel valleys do not usually have overflood terraces. In addition to accumulative terraces, there also occur erosive and erosive-accumulative terraces.

It is already conventionally accepted, that $15 \mathrm{~km}$ long valleys are ranked as a variation of landscape. These valleys have well-formed floors and slopes. The sediment lithology is varied in these valleys. Only a few, usually narrow valleys (1-3), often have erosive overflood terraces. The statement that $15 \mathrm{~km}$ long valleys are ranked as a variation of landscape is controversial. In our opinion, there is a need to distinguish, in the area of the last glaciations, a separate sort of land- scape - channel valleys. Subglacial channels (both fluvioglacial and glacial) would belong to the channel valleys. The reasons for this are presented later in this paper, in the section about the characteristics of these kinds of valleys.

It was not possible to show on a map with a scale of 1: 200000 (Fig. 2), the separate fragments of the erosive and erosive-accumulating overflood terraces. For this reason, the terraces were often seen together, except the floodplain in the Vistula Valley. The lowest accumulating overflood terrace, and the tall valley and channel slopes, however, were differentiated. This caused the distinctions within the valleys to increase to $7 \mathrm{kinds}$ and 13 variations (see Table 2)

\section{Kinds and variations of the natural landscape of the river valleys}

The valleys of Drwęca and Vistula that belong to this category, started forming about $16 \mathrm{ka}$ BP. These valleys have widely developed overflood terraces (up to $10 \mathrm{~m}$ ) and flood plains. The valley of Skrwa can also be included in this category. The Skrwa Valley was formed on the sandur trail, about 15 ka BP. Within the Skrwa Valley, there are 7 overflood terraces which are only in the floor section (Andrzejewski 1994). The valleys with small rivers (15-40 km long) also belong in this category. These valleys started forming in the late glacial period (14-11 ka BP) and have 1-4 overflood terraces. The terraces of the valleys of small rivers could not be accounted for on a map the scale of 1: 200000 (Fig. 2). Kinds and variations of the natural landscape of big river valleys are described and differentiated below.

\section{The landscapes of the area of the river val- ley slopes}

This kind of landscape occurs on the slopes of the Vistula and Drwęca Valleys. The height of the valley slopes depends on what kind of terrace appears on the floor of the valley. This is why the height varies from 10 to $50 \mathrm{~m}$. The relief of this landscape is varied and depends on the age of the slopes. The slopes are adjacent to the overflood terraces. 
In this case, the slopes were created mainly in the periglacial climate, with permafrost. This is why these kinds of slopes have a degradation sphere with a width of about 0.5 $\mathrm{km}$. Trough valleys (about $10 \mathrm{~m}$ ) and deeper flat-floored valleys of an arroyo type, cut along the slope of this degradation sphere. In the Drwęca Valley, the arroyos are usually dry and dead. In the Vistula Valley, the arroyos were deepened to $40 \mathrm{~m}$. The height of the slope is variable and reaches $20-50 \mathrm{~m}$. On the floor of the slopes, denudation covers can often be seen. Alluvial fans can be seen at the exit of the arroyos. In the Holocene epoch (and still today), in the Drwęca Valley and mainly in the Vistula Valley, some parts of the slopes were washed out by the erosion action of the river. This is why the slopes are retreating and moving further away. Very steep slopes without a degradation and aggradation zone were created as an effect of the erosion. On the steep slopes, clay - landslide movements take place. The landslide movements are on the right slope of the Vistula River, between the cities of Płock and Włocławek and near the left slope of the Fordon Valley.

Except for the varied relief of the terrain, a distinctive feature for this zone is the differentiation of the sediment lithology, and a specific soil system and vegetation. This soil system has pedoecotone characteristics (Bednarek and Prusinkiewicz 1980). Research by R. Kot (2006) showed that it is in the zone of the slopes (for example in the area of Jarużyn, Trzęsacz-Gądecz, Topolno, Kiełp, Płutowo-Szymborno, Strzyżawy-Pień), that geodiversity is the greatest.

There are 2 distinct variations of landscape in this kind of landscape.

18- The forestless landscape of river valley slopes, grassland, pastures

This landscape includes part of the Drwęca and Vistula slopes. Only the denudation flattening and a few mild slopes are used for faming purposes. There are fruit orchards on the artificial terraces of the slopes of the Vistula Valley (and among others, in the Fordońska Valley). On most of the forestless slopes there is grassland vegetation used as pastures. In Kulin (in the area of the city of Włoclawek), and on the right slope of the Unisław Basin, there are xerothermic grasslands with step vegetation (within the "Zbocza Plutowskie" Reserve).

19- The forested landscape of river valley slopes

This area includes forests that have a similar structure to natural leafy dry-ground forest. This is the zone with slopes and deep arroyos which are hard to reach. These kinds of forests appear in the area of the village of Ostromecko ("Las Mariański" Reserve), near the village of Wielkie Lunawy in the Vistula Valley. Patches of the dry-ground forest are also seen in the Drwęca area.

\section{The landscapes of the flat erosive-accu- mulative terrace plain}

These are landscapes of the flat erosive-accumulative terrace plains of the Vistula and Drwęca Valleys, and small fragments of the lower Skrwa Valley. The erosive terraces have river sand-gravel sediments (the sediments are $0.5-2.0 \mathrm{~m}$ deep) These terraces usually appear on the washed-out boulder clay. The erosive-accumulative terraces with $2-5 \mathrm{~m}$ river sediments, are sand-gravely (sometimes with fine sand and a bit of loam). All terraces are flat and separated from each other with curves of different heights (a few meters). The number of terraces increases downstream. The biggest terraces (XI, X) in the Drwęca Valley and in the Torun Basin, were formed by glacier water. There are kettle depressions of various sizes within the terraces. In the Drwęca Valley, the terraces are found together with subglacial channels and rarely seen postglacial lakes (for example Okonek, Jezuickie Lake and others). The biggest reservoir of a kettle origin is the Rukatowskie Wielkie Lake in the Plock Basin (300.5 ha). The soils are mainly rusty soils (half-bog, and organic soils) (BRUNIC ARENOSOLS, MOLLIC GLEYSOLS DRAINIC, HISTOSOLS IUSS WORKING GROUP WRB 2007).

Due to the similarity in the relief of the terrain and the lithology of the sediments, 2 
variations of landscape were distinguished. These distinctions were made based on the vegetation and use of the terrain.

20 - The landscape of the forested overflood, erosive-accumulative terraces

Big forest complexes occur in the Drwęca Valley, in the Konstancjewo and Elgiszewo Basins, and in the Vistula Valley (usually near dunes). The most common kind of forest complex is the pine tree forest. In the Konstancjewo Basin, there are patches of short dry-ground forest with Polish larch. In the valley of the lower Skrwa and in the neighboring area within the Brudzeń Landscape Park, riparian-elm forests exist.

21- The landscape of the overflood, erosive-accumulative terraces with agricultural $\underline{\text { land }}$

This landscape occurs mainly, but not only, on erosive terraces. The water level of the soils on these terraces is shallower, and the sediments are less sorted. The surface of these terraces are used as agricultural land or pastures. The plants cultivated on this land have fewer soil requirements. Forestless, biogenic plains are also found on the terraces.

12. The landscape of plain erosive-accumulative terraces, with dune ridges and hummocks

Within this kind, only 1 variation is identified.

22- This is the landscape of flat overflood, erosive-accumulative terraces with dispersed dune hummocks and ridges, and with agricultural land and patches of pine forest

This variation of landscape is in the Plock Basin, between the Pfock and Torun Basin, and in the Torun Basin. The dunes which occur in the Basins do not form compact complexes. The dunes are scattered, smaller (not more than $20 \mathrm{~m}$ ) and formed as ridge dunes, parabolic dunes, hummocks and acolian covers. The terraces form flat plains, separated with terrace edges. The terraces are rarely varied with biogenic floor sediment depressions. Agricultural use is differentiated. The dunes are mainly overgrown with mixed forests, and pine forests. Nearby terrace layers are forested, and next to the mixed forest, here are patches of poor quality dry-ground forest (in the area of the "Las Piwnicki" reserve north of Toruń). Sometimes, terraces are used as agricultural land or pastures.

\section{The landscape of plain accumulative ter- races, with dune hummocks and ridges}

This terrace is widely developed on the right side of the Torun Basin, and on the right side of the Grudziądz Basin, and in the area of the city of Ciechocinek. On the remaining sections, in the Vistula, Drwęca and Skrwa Valleys, this terrace appears in the form of long, narrow strips. In the Vistula Valley, the terrace rises $5-8 \mathrm{~m}$ above the level of the Vistula River. The flat accumulative terrace is considered as different from the higher terraces because this terrace is built mainly with medium and small sized sands, and the sands are better sorted. The thickness of the river sediments sometimes exceeds $10 \mathrm{~m}$, making the thickness greater than the height above the river level of the terrace. This terrace is only dunned in the area of the Vistula Valley (terrace-dune landscape). Distinctive features of the relief of the terrace in the Torun Basin, and in the area of the city of Ciechocinek, are specific, long depressions. These depressions are former stream channels of winding rivers. The rivers created peat, muck, and alluvian peat which then dried out and these areas are now used as agricultural land, pastures and meadows. Sometimes in the Torun Basin, Unisław and Świecie Basin, the terrace remained in the form of narrow strips with low aeolian ridges.

Within this terrace, 2 variations of landscape are identified.

23- The landscape of a flat overflood, accumulative terrace plain, with dispersed forested dunes

As in variation no. 22 , the dunes on this landscape have various shapes. However, the main dunes have low ridge forms. Parabolic dunes play a minor role in this landscape. In the Grudziądz Basin, dunes and forests surrounded the Duże Rudnickie Lake (160.9 ha and max. depth $11.9 \mathrm{~m}$ ) and other lakes. 
24- The landscape of the flat overflood. accumulative terrace plain, agricultural land Forestless, sandy terrace patches, with poor rusty soils (BRUNIC ARENOSLOS IUSS WORKING GROUP WRB 2007), are used for agricultural purposes. The former stream channels with rivers and peat kettle depressions after melioration are sometimes used for agricultural purposes but mainly as pastures and meadows. In the region of Ciechocinek, therapeutic mud is utilized for medical purposes. The low dune ridges are without forests and are covered with grassland.

\section{The landscape of flat flood plains}

The flood plain is best developed in the Vistula Valley. Less developed flood plains occur in the Drwęca and Skrwa Valleys. The width of the less developed plains varies from 100 to $500 \mathrm{~m}$, although in the Drwęca Valley the width reaches $1 \mathrm{~km}$. In these valleys (Vistula, Drwęca and Skrwa), the plain is not continuous. Within the Vistula Valley, in the Płock Basin, most of the plain was flooded with water from the Wloclawek Reservoir. Only a narrow strip of the plain remains on the left side of the Wlocławek Reservoir. Below the Reservoir, the plain is continuous. In the narrowing of the Reservoir the width of the plain varies from 0.5 to $5.0 \mathrm{~km}$. In the Unislaw Basin, the width of the plain reaches about $8 \mathrm{~km}$. There are usually 2 levels on the flood plain in the Vistula Valley. The flat plain is varied with dunes which have stream channel patterns, and with depressions of former riverbeds. In the overgrown, old stream channels, organic sediments of mainly peat commonly occur. On the surface of all the mentioned valleys, there are flood facies sediments (thickness 3-4 m). In places with fossil peat, the thickness of the flood facies is only $0.5-1.5 \mathrm{~m}$. The main sediments of this facie are alluvial soils in the form of sandy and clay loam, and fine-grained sand. The surfaces of the berms and small river or lake islands are also built from fine sand. In the XIX century, the Tążyna River was regulated and flood banks were erected providing the flood plain with protection from floods. In the Drwęca and Skrwa Valleys, the allu- vial soils (FLUVISOLS IUSS WORKING GROUP WRB 2007) are not so thick and they contain more fine sand.

On the plain described above there are 2 variations of landscape.

25- The landscape of flat flood plains with arable land and meadows

Arable land is most common in this area and vegetables are cultivated here. In the Unislaw Basin mint is also cultivated. There are pastures and meadows on parts of the Vistula, Drwęca and Skrwa Valleys.

26- The landscape of forested flat flood plains

The original vegetation was riparian forests. The riparian forests only remain in small patches of the Kępa Bazarowa Reserve in Torun, on the Kępa Ostromecka, in the Ostrów Panieński Reserve near Chełmno, and in a few more places (see Fig. 2). There are very few small river valleys $(15-40 \mathrm{~km})$ and they are mainly in the area of the Vistula Valley. The melting of blocks and pieces of buried ice helped create these small river valleys. Lakes also existed in the created depressions. These lakes became more and more overgrown until they turned into peatlands. Clearly seen are the river valleys with 1 to 3 overflood terraces. These river valleys occur outside the peatlands, mainly on the high terrace steps. The Zielonka and Jordan Valleys in the Torun Basin, and the Rakutówka Valley in the Płock Basin have these characteristics. In the Dobrzyń Lakeland, the most typical example of a river valley is the $10 \mathrm{~km}$ section of the Pissa River (the tributary of Brynica) in the Vistula Valley. Within the moraine plateau, the $10 \mathrm{~km}$ section of the Pissa river is a canyon valley (up to $150 \mathrm{~m}$ wide, $20 \mathrm{~m}$ deep), containing fragments of 3 overflood terraces.

\section{Kinds and variations of the natural landscape of channel valleys}

As previously mentioned, the channel valleys were created subglacionally in the glacial period. After the ice sheet disappeared, the channel valleys remained. Inside the channel valleys, there were blocks of ice covered with mineral sediments. The blocks 
of ice begun to melt about 2-3 thousand years later, in the late glacial period. In this period channels materialized, and numerous channel lakes appeared. In the study area, there are big subglacial channels - for example, the Chełmża subglacial channel, the Lutryna and Rypienica subglacial channels (both up to $30 \mathrm{~km}$ long, $0.5-2.0 \mathrm{~km}$ wide and $30-50 \mathrm{~m}$ deep). Smaller subglacial channels of over a dozen $\mathrm{km}$ long, a couple hundred $\mathrm{m}$ wide and 10-20 $\mathrm{m}$ deep, also appear in the study area. Specific feature of most subglacial channels are the enlargements and narrowings, steep slopes $\left(40-50^{\circ}\right)$, and uneven floors. In all subglacial channels, there existed smaller or bigger lakes which are now extinct with the exceptions of the lakes which are still present in the channel valleys of Lutryna, Struga Wąbrzeska and Ruziec. The lakes which became extinct turned into peat plains. On the study area, there are also subglacial channels which were not transformed by rivers. However, the subglacial channels were not included on the map (Fig. 2). Those subglacial channels not transformed by rivers are primarily channels which still have lakes. Examples are most of the Chełmża and Steklin subglacial channels, and most of the small subglacial channels which are elements of different variations of landscapes.

The channels have been transformed by rivers in various degrees and stages (Niewiarowski 1986). The transformation was usually mild, because in some channels drumlins remained (the Górzanka glacial channel near Górzno), and kámes-mainly kame terraces (the channels of Brynica, Ruziec, Mień and Rypienica). Only aligned floors remained in the channels. After the lakes became extinct, extensive peat plains developed. Numerous channels have small erosive sections formed from the river receding and expanding. Other parts of the channels have a peat floor (the Lutryna, Rypienica and Struga Kowalewska channels). The Struga Wąbrzeska and Ruziec rivers use two channels. Those two channels combine at the erosive river sections between the channels. The marginal channel is the most changed, having been transformed by the Osa river.
A valley $0.3-0.5 \mathrm{~km}$ wide, with a steep slope, 4 overflood terraces, and $30-50 \mathrm{~m}$ deep, formed in this channel. This valley is located between the villages of Swiecie (Osa river) and Kłódka. The slopes of the channel valleys are made up of various sediments, especially clay-sand sediments. The floors of the channel valleys are made of peat, and the verge of the channel is mainly made of clay and sand. Lake terraces (mainly older generation lakes) made of gyttja, peat and lake limestone, can be found in some channels.

A channel landscape must be distinguished not only by the origin of the channel but also the morphology (i.e. lack of terraces), the lithology of the sediments, and the vegetation and land use. It is the vegetation and land use which differs these kinds of channel valleys from river valleys that were subaerially formed.

Part of the channel valleys share characteristics with those of the complex valley. The channel valleys have long channel sections on the moraine plateau, but short erosive sections within the Vistula Valley area (Mień and Osa rivers). In the channel valleys, there are parts of erosive complex valleys of the Zglowiączka, Tążyna and Left Skrwa rivers shown on the map (Fig. 2). Erosive sections of the Rypienica, Ruziec, Lubianka and Struga Wąbrzeska rivers occur within the area of the Drwęca Valley. Channel parts of some tributaries of the Drwęca river, (the Struga Kowalewska and Struga Rychnowska rivers) remain. Erosive sections usually reach a couple hundred meters in width, with various depths (a few - to over a dozen meters), and 1-3 overflood terraces (erosive terraces). Four variations can be distinguished within all of these valleys. On the map, due to the scale (Fig. 2), only examples can be shown.

\section{Landscapes of high slopes of subglacial channels}

In this kind, 2 variations are identified.

27- The landscape of high slopes of subglacial channels with rivers and pastures

These channels have more or less been transformed by the rivers. This variation of land- 
scape occurs only on the high slopes (over 20 $\mathrm{m})$ of deep channels, for example, the Rypienica, Ruziec, Browina, Osa Channels. In contrast to the slope zones of the Vistula and Drwęca Rivers, the degradation and aggradation is less developed. The slopes of the subglacial channels are not cut by periglacial valleys, but Holocene erosive slits. This landscape is without forests, and is covered with grassland and pasture vegetation.

28- The landscape of high slopes of subglacial channels with leafy forests

This landscape refers mostly to the slope zone of the river Osa, in the Brynica Channel part, and small patches of other channel valleys.

\section{The landscapes of terraces and floors of} subglacial channels with rivers

Two variations of landscape are identified here.

29- The landscape of terraces and floors of subglacial channels with rivers, pastures and meadows

This landscape occurs mainly in the complex channel valleys. The slopes are mild, and the borders are used as farmland, the steep slopes are covered with pastures, and on the floor there is meadow vegetation.

30- The landscape of terraces and floors of subglacial channels with rivers, leafy forests There are strips of riparian forests on the valley floors. The biggest patch of the almost natural original forest is in the Landscape Reserve of the Osa Valley. The patches of forest in the Brynica Valley, within the "Jar Brynicy" Reserve are also similar to those in the Landscape Reserve.

\section{III.The landscape of biogenic depres- sions and plains}

In genetic terms, 2 types of depression occur in this landscape:

a.) Depressions formed from the melted dead ice

b.) Depressions in the former stream beds and branches of winding meandering rivers, and in the so called "flood basins".

In all the depressions, despite the varied surface, shape, depth and age, there were accumulations of minerogenic and organic (biogenic) sediments.

\section{The landscape of flat biogenicplains}

Only 1 variation is distinguished.

31- This is landscape of flat biogenic plains with pastures and meadows

The biogenic plains mainly include peat plains. These peat plains were created from the extinct lakes or as a result of the peat overgrowing the area mainly in the river valleys, due to groundwater growth. On the biogenic plains, peat as well as alluvial peat, gyttja, and lake limestone of an organic origin can also be found. These plains are without forests and are located on bogs. After melioration and drying out, the plains are sometimes used for agricultural purposes, but mainly as pastures and meadows. In some places on the peatlands, peat has been extracted for commercial purposes.

How much of the biogenic plains can be defined as variation of landscape, has not yet been established. In this article, plains larger than $1 \mathrm{~km}^{2}$ are defined as types. The plains rarely appear on moraine plateaus, but do occur in the sandur areas (like the Bagno Zgnilka on the Wąbrzeźno sandur), in the floors of the channels, and in the Drwęca Valley. Most commonly the plains appear in the Vistula Valley (see Fig. 2)

\section{SUMMARY AND DISCUSSION}

The landscape is a real, heterogeneous spatial unit, which denotes that the class, sort and kind of landscape, but also the variation, are composite in nature.

Views on the distinguishing of natural landscapes have evolved, at times in a very significant way. An example might be the introduction of 4 classes of natural valley and depression landscape, as proposed by Richling (1984), compared with the earlier work by J. Kondracki $(1960,1981)$. Doubts regarding the landscapes identified, the rank appropriate to them and the criteria used in delimitation will always exist, this reflecting the differing possible approaches to the matter. 
The process of identifying "natural units" should take account of all components, including modifications induced by human activity. This is not always possible, e.g. on account of the level of reconnaissance achieved at the given time or the lack of studies drawn up most often on detailed scales. It is for this reason that the delimitation of units often takes selected criteria into account. The precise choice of these depends on the scale of the elaboration as well as the kind of area analysed (mountain, upland or lowland). As units (landscapes) are being discerned on the global scale, it is climate that play the main role. In contrast, on the more detailed scales (such as those of the country or region), the leading role is most often ascribed to geological structure and relief, as for example when classes, sorts and kinds under the typology developed for the natural landscape by A. Richling (1992) are being distinguished.

The delimitation of landscapes also needs to entail the (at least) attempted resolving of what remains the very important problem of the threshold sizes and quantities beyond which objects like dunes, depressions (kettle holes), subglacial channels and so on can be deemed to belong to a separate class of landscape, as opposed to being elements within a defined landscape type. Thus, how large a dune or how many dunes, or how large á subglácial channel, or how large a depression (kettle hole) or how many depressions (kettle holes) belong respectively to the lowland class and aeolian sort, the class of valleys and depressions and the sort of channel valleys, or the class of valleys and depressions and the sort of depressions, as opposed to constituting an element within other classes. It is hard to imagine, for example, that among the undulating morainic plateaus, all (even the smallest) examples of depressions (kettle holes), or the biogenic plains or marshy/accumulation plains identified by A. Richling (1992) will be included within the separate class of valleys and depressions, and not the class of lowlands within which they will certainly represent component elements. Large subglacial channels or parts thereof $(27,28,29,30)$ are separate types, or in the case of small forms are elements of other types (as in the case of variation 6).

The present article thus has a certain proposal to make when it comes to the factor of size (e.g. the size of valleys in excess of $15 \mathrm{~km}$ in length is regarded by convention as indicative of a variation, as variation is a depression covering upwards of $1 \mathrm{~km}^{2}$ ). The justification or sense behind this conceptualisation remains a matter for debate, but the scales on which landscape maps are devised and areal reconnaissances carried out requires that such work engage in certain generalisations of the kind applied in this case.

The authors of this article, based on their own field research, and many cartographic materials and scientific literature, have identified in the study area, the titles (Fig. 1,2, Table 2), sorts, and kinds of landscape not included in A. Richling's typology (1984, 1992) of Polish natural landscape (1984, 1992). Richling's typology is shown in Table 1. Instead of the term "fluvioglacial landscape" in the lowland landscapes, we have applied the term "glacioaquatic landscape. This is because glacioaquatic landscape includes not only fluvioglacial but also the limnoglacial landscapes. Within the valleys and depressions category, we offer an additional sort; the channel valleys. The origin and morphology of the channel valleys differ fundamentally from the river valleys. The river valleys were created in subaerial conditions. Furthermore, we have explained that within the lowlands class, the criteria for distinguishing kinds of the landscape should be broader. In addition to the flat and undulated plains, hummocks and hillocks there should also be differentiations made between: flat and undulated plains, ridge landscapes, undulated-hummock, undulated-hummock-ridge landscapes, complex hummocks and ridge lândscápes, and morphometric characteristics should be given. In the valleys and depressions class, the authors also recommend distinguishing the kinds of erosive-accumulative terraces, and high slopes of valleys and channels. 
Expanding the criteria for distinguishing landscapes increased the number of landscape kinds to 17 . This more clearly shows the real differentiation of the landscapes. We have decided, that for distinguishing the variations of landscapes within the Polish Lowlands, the criteria used by R. Galon (1984) are much more useful than A. Richling's (1984) criteria of the natural landscape typology. Based on the new, more detailed field research and new cartographic materials, we were able to identify more variations of landscapes (31) on our study area, which was bigger then R. Galon's (1984) study area. The names are now strictly defined and the landscapes have been included on the map for the first time (Fig. 2). The listed characteristics of variations of landscapes enrich the literature, as landscapes have been poorly described up till now. The information about the variations of landscapes can be used for practical purposes, for example, in spatial planning.

Some divisions of landscape kinds and especially the variations divisions, are controversial and will probably change in time. The variations of the natural landscape described do not comprise one type of geosystem (geocomplex). They were identified on the basis of a set of criteria, and they comprise all the components (criteria described in more detail are a bais for both delimitation and a more modest characterisation of remaining features). In A. Richling's (1984, 1992) typology, it is assumed that when distinguishing the variations of landscape, the only criteria for the whole area of Poland are the lithology of the sediments, and the land use. However in previous studies, J. Kondracki (1981) and R. Galon (1984) stated that relief is the important criterion for identifying the landscape variations. In distinguishing the "types of landscape" in the studies of A. Richling's and others (2005), it has been assumed that the main criteria are relief combined together with the lithology of the sediments, and the land use expressed in "landscape variants". These are the same criteria we use for variations of landscape. Similar criteria (relief/topography, lithol- ogy and land use) were also applied on a less detailed scale for part of Europe as a whole (C.A. Mücher et al. 2003).

In A. Richling's $(1984,1992)$ typology of natural landscape, the flat plains and the undulated plains are considered as one. This is fully justified, though with a lack of data. In A. Richling's newer publication (2005), it is assumed that plain terrains have drops from 0 to $2 \%$, but $2 \%$ is only $1.15^{\circ}$. These kinds of drops are even too small for flat plains with $2^{\circ}$ drops (this is about $3.5 \%$ ). In geomorphology, it is commonly assumed that in the area of the Polish Lowlands, there are drops from 2 to $5^{\circ}$ on the undulated plains. That is $3.5-8.75 \%$. A. Richling et al. (2005) also do not explain why they combine the flat plains and undulated plains into one category. They also do not explain why they assume $2-5 \%$ drops for the plains, and $2-10 \%$ drops on the low hummocks, when in reality on the undulated plains, the drops are, as mentioned above, $3.5-8.75 \%$, and on the hummocks and hillocks, the drops usually vary between 5 and $17^{\circ} ; 9-30 \%$.

It is worth noting that for the first time in Richling's typology, slope landscapes were distinguished within the kinds of landscape (Richling et al. 2005). The slope landscapes had previously been identified by R. Galon (1984). However, the ridge landscapes have still not been distinguished by anyone, although the ridges themselves are included in various descriptions. When characterizing the types of landscape, the term "plateau surfaces"s" is still ambiguous. For example, when describing the landscape type of the "undulated and hummock plateau surfaces with clay and loam". As it is commonly known, the hummocks and hillocks are convex forms. These convex forms occur on the plateau plain but are varied with concave forms. Thus, the surface of the plateau is not uniform. The clays and loam occur, for example, on some hummock and kame plateaus, and in the depressions and plains of deposits or lake sediments. The clays and loam are not typical for plateau surfaces.

Despite detailed studies, the lithology of the sediments is very general in the 
newest landscape typology (Richling et al. 2005). Aside from sand-gravel hummocks and hillocks, only aeolian hummocks and hillocks have been identified. Moraine hummocks and hillocks made of heap clays and clay-sand sediments are omitted in Richling's typology.

The above mentioned differences in the understanding of the relief and lithology of sediments mean that the kinds and variations of landscape identified by us (for the area of the last glaciations) only share the general outlines of the landscape kinds and "types of landscape" of A. Richling et al. (2005).

The above mentioned inaccuracies in the discussed publication do not lessen our appreciation for A. Richling's enormous contribution to the typology of the natural landscape of Poland and to many other aspects of the field. Also, we respect A. Richling's contribution of additional, more precise identification concerning the concept of landscape as well as determining the structure and function of landscape.

It was the huge output of A. Richling and others that inspired the authors to become involved in the discussion regarding the delimitation of natural landscapes where the Chełmno-Dobrzyń Lakeland and adjacent valleys of the Vistula and Drwęca are concerned. These regions are lacking in studies elaborated on such a detailed scale.

\section{CONCLUSIONS}

The detailed analysis of natural landscapes of the Chelmno-Dobrzyń Lakeland, Urszulewo Plain and neighbouring Vistula and Drwęca valleys has allowed the authors to draw the following conclusions:

The study is diverse enough to allow for the identification of 17 kinds and 31 variations of natural landscape. Within the lowland class, the name of one sort of landscape has been changed to glacioaquatic. In turn, the class of valley and depression landscapes now incorporates a new sort comprising the channel valleys. Two classes have also been extended to include new kinds of landscape, for example: ridges, river valley slopes, high slopes of subglacial channels (Table 2).

The employed set of criteria: relief (hipsometry and morphography), lithology and land use are suited to the identification and delimitation of landscapes on the Polish Lowland. Similar criteria for the area of Poland were also applied by R. Galon (1984) and A. Richling et al. (2005), as well as for a part of Europe on a more generalised scale of elaboration, by C.A. Mücher et al. (2003). The landscapes of differing rank identified may be used in a division into physico-geographical regions, to determine more precisely the courses to the boundaries of mesoregions and to distinguish of microregions. Furthermore, knowledge on their relevant components may be put to use in spatial planning.

Thanks to the authors of the article having taken up the matter of the identification of natural landscapes on the Polish Lowland, it will now be possible for views on this to be presented, with a view to the academic discussion in this field being enriched.

\section{REFERENCES}

Andrzejewski, L. (1994), Ewolucja systemu fluwialnego doliny dolnej Wisty w póznym vistulianie $i$ holocenie na podstawie wybranych dolin jej doptywów [The evolution of the fluvial system of the lower Vistula in the late vistulian and holocene epoch, based on chosen valleys of the Vistula's tributaries), Wydawnictwo UMK, Toruń.

Bednarek, R., Prusinkiewicz, Z. (1980), Geografia gle $b$ [The geography of soils], PWN, Warszawa.

Bednarek, R., Prusinkiewicz, Z. (2001), Zróznicowanie i rozmieszczenie gleb [Differentation and location of soils], in Przystalski, A. (ed.), Przyroda województwa kujawsko-pomorskiego [Nature in the Province of Kujawsko-Pomorskie], Kujawsko-Pomorski Urząd Wojewódzki, Bydgoszcz, 33-40.

Bednarek, R., Jankowski, M. (2006), Gleby [Soils], in Andrzejewski, L., Weckwerth, P., Burak, S. 
(eds.), Toruń i jego okolice: Monografia przyrodnicza [Toruń and surroundings: the Monography of nature], UMK, Torun, 153-175.

Borowiec, S. (1968), Zadania, treść i przydatność map siedliskowo-rolniczych [The tasks, the content, and the use of habitat-agricultural maps], Biuletyn KPZK PAN، 50, Komitet Przestrzennego Zagospodarowania Kraju, Warszawa, 30-50.

Ceynowa-Gieldon, M. (1984), Roślinność [Vegetation], in Galon, R. (ed.), Województwo toruńskie: przyroda-ludnośc-osadnictwogospodarka [The Torun Province: nature -population - colonization - economy], Wydawnictwo Naukowe PWN, WarszawaPoznań-Toruń, 207-239.

Churska, Z., Kwiatkowska, E. (1964), Rozwój osadnictwa i stosunki gospodarcze okolic Czernikowa w powiązaniu ze środowiskiem geograficznym [The development of settlements and economic relations in the area of Czerniakowo in conjunction with the geographical environment], Zeszyty Naukowe UMK, Geografia, 3: 135-168.

Churski, Z., Liberacki, M., Kotarbiński, J., Niewiarowski, W., Wójcik, C. (1978), Mapa Geologiczna Polski 1:200 000, arkusz Brodnica [Geological Map of Poland 1:200 000, Brodnica sheet], pub. A, Instytut Geologiczny, Warszawa.

Forman, R.T.T., Godron, M. (1986), Landscape ecology, J. Wiley \& Sons, New York.

Galon, R. (1984), Typy krajobrazu naturalnego i regiony fizycznogeograficzne [Types of landscape and physico-geographical regions], in Galon, R. (ed.), Województwo toruńskie: przyroda-ludność-osadnictwo-gospodarka [The Province of Torun: nature - population - colonization - economy], Wydawnictwo Naukowe PWN, Warszawa-Poznań-Toruń, 251-259.

Instrukcja do Szczególowej Mapy Geomorfologicznej Polskiego Nizu 1:50 000 [Instructions for Detailed Geomorphological Maps of the Polish Lowland 1:50 000]. Zaktad Geomorfologii i Hydrografii Niżu IG PAN, Toruń, 1962.

IUSS Working Group WRB; 2007. World Reference Base for Soil Resource 2006, first update 2007. World Soil Resources Reports No. 103. FAO, Rome.
Kalinowska, K. (1961), Zanikanie jezior polodowcowych w Polsce [The disappearance of glacial lakes in Poland], Przeglad Geograficzny, 33, 3: 511-518.

Kępczyński, K. (1965), Szata roślinna Wosoczyzny Dobrzyńskiej [Vegetation of the Dobrzyn Plateau], UMK, Toruń.

Kępczyński, K. (1973), Szata roślinna doliny dolnej i środkowej Drwęcy oraz terenów do niej przylegtych [The vegetation of the lower and middle of the Drwęca Valley and adjacent areas], Acta Universitatis Nicolai Copernici, Geografia, 9, UMK: 123-158.

Kondracki, J. (1960), Typy krajobrazu naturalnego (środowiska geograficznego) w Polsce [Types of natural landscape (geographical environment) in Poland], Przeglad Geograficzny, 32, 1-2: 23-33.

Kondracki, J. (1981), Geografia fizyczna Polski [Physical geography of Poland], Wydawnictwo Naukowe PWN, Warszawa.

Kondracki, J. (1998), Geografia regionalna Polski [Regional geography of Poland], Wydawnictwo Naukowe PWN, Warszawa.

Kondracki, J., Richling, A., (1983), Próba uporządkowania terminologii w zakresie geografii fizycznej kompleksowej [An attempt to organize the complex terminology of physical geography], Przeglad Geograficzny, 55, 1, 201-207.

Kot, R. (2006), Georóżnorodność - problem jej oceny i zastosowania w ochronie i kształtowaniu środowiska na przykladzie fordońskiego odcinka doliny dolnej Wisły i jej otoczenia [Geodiversity - the issue of its evaluation and application in conservation and forming of the environment on the example of the Fordon's part of the lower Vistula valley and its surroundings], Studia Societatis Scientiarum Torunensis, Series C, 11, 2, Torún.

Kotarbiński, J. (1966), Budowa i wiek moren czolowych w okolicy Gozdowa na Wysoczyźnie Plockiej [Structure and age of the end moraines in the area of Gozdow on the Plock Plateau], Przeglad Geograficzny, 38, 1: 107-115.

Liberacki, M. (1969), Mapa Geomorfologiczna Polski 1:50 000 [Polish Geomorphological Map 1:50 000], arkusz Lipno [Lipno sheet], IG PAN, Torun.

Mrózek, W. (1958), Wydmy Kotliny Toruńsko-Bydgoskiej [Dunes of the Torun-Bydgoszcz Ba- 
sin], in Galon, R. (ed.), Wydmy śródladowe Polski [Polish inland dunes], Vol. 2, Wydawnictwo Naukowe PWN, Warszawa, 7-59.

Mucher, C.A., Bunce, R.G.H., Jongman, R.H.G., Klijn, J.A., Koomen, A.J.M., Metzger, M.J., Wascher, D.M. (2003), Identification and characterisation of environments and landscapes in Europe, <http://content.alterra.wur. $\mathrm{nl} /$ internet/webdocs/internet/geoinformatie/ projects/LANMAP2/publications/Alterrarep832.pdf, (15.11.2011)>.

Mucher, C.A., Klijn, J.A., Wascher, D.M., Schaminée, J.H.J. (2010), A new European landscape classification (LANMAP): A transparent, flexible and user-oriented methodology to distinguish landscapes, Ecological Indicators, 10: 87-103.

Nechay, W. (1927), Utwory lodowcowe Ziemi Dobrzyńskiej [Glacier forms in the Dobrzyń Land Region], Sprawozdania PIG, Państwowy Instytut Geologiczny, Warszawa, 4, 1-2.

Niewiarowski, W. (1957), Wybrane zagadnienia z badań geomorfologicznych na arkuszu „Mazowsze" mapy 1:25 000 [The "Mazowsze" Map 1:25000 used in selected aspects of geomorphological studies], Dokumentacja Geograficzna, 3, Warszawa, 24-37.

Niewiarowski, W. (1959), Formy polodowcowe i typy deglacjacji na Wysoczyźnie Chelmińskiej [Postglacial forms and deglaciation forms in the Chelmno Plateau], Studia Societatis Scientiarum Torunensis, Series C, Torun, 4, 1.

Niewiarowski, W. (1968), Morfologia i rozwój pradoliny i doliny dolnej Drwęcy [Morphology and development of the ice-marginal valley and the Lower Drwęca Valley], Studia Societatis Scientiarum Torunensis, Series C, Toruń, 6, 6.

Niewiarowski, W. (1986), The phases of transformation of subglacial channels into river valleys: a case study of the Lower Vistula Region, Acta Universitatis Nicolai Copernici, Geografia, 21: 61-72.

Niewiarowski, W., Kot, R. (2010), Delimitacja i charakterystyka gatunków i odmian krajobrazu naturalnego Pojezierza Chelmińsko-Dobrzyńskiego, Równiny Urszulewskiej oraz przyleglych dolin Wisły i Drwęcy [Delimitation and characteristics of natural landscape kinds and variations of the Chetmno-Dobrzyń Lakeland, Urszulewo Plain and neighbouring Vistula and Drwęca valleys], Przeglad Geograficzny, 82, 3: 335 366.

Olszewski, A. (1994), Zbójeński obszar drumlinowy [Zbójno drumlin area], in Wiśniewski, E. (ed.), Formy, osady i procesy subglacjalne. Sympozjum [Forms, sediments and subglacial processes Symposium], Toruń-Górzno 28-29 Sept. 1994, Instytut Geografii UMK, Toruń, 44-53.

Olszewski, A. (1997), Drumlins of the northwestern Dobrzyń Moraine Plateau: location, structure and morphogenesis, Quaternary Studies in Poland, 14: 71-83.

Podgórski, Z. (1996), Antropogeniczne zmiany rzeźby terenu województwa toruńskiego [Anthropogenic changes in the relief of the Province of Toruń], Studia Societatis Scientiarum Torunensis, Series C, Toruń, 10, 4.

Rejewski, M. (1971), Lasy liściaste Ziemi Chetmińskiej [Deciduous Forests of the Chelmno Land Region], Studia Societatis Scientiarum Torunensis, Series D, Torun, 9, 3.

Richling, A. (1972), Struktura krajobrazowa Krainy Wielkich Jezior Mazurskich [The Landscape Structure of the Great Masurian Lakes], Prace Instytutu Geografii UW: 10, Geografia Fizyczna, 4, Warszawa.

Richling. A. (1984), Typology of natural landscape in Poland on the scale 1:500 000, Miscellanea Geographica, Warszawa, 27-32.

Richling, A. (1992), Kompleksowa geografia fizyczna [Complex physical geography], Wydawnictwo Naukowe PWN, Warszawa.

Richling, A., Dąbrowski, A. (1995), Typy krajobrazów naturalnych [Types of Natural Landscapes], plansza [chart] 53.1, in Atlas Rzeczypospolitej Polskiej [Atlas of the Republic of Poland], Glówny Geodeta Kraju, Instytut Geografii i Przestrzennego Zagospodarowania (IGiPZ), PAN, PPWK im. E. Romera S.A., Warszawa.

Richling, A., Malinowska, E., Lechnio, J. (2005), Typologia i regionalizacja krajobrazów terenów w strefie oddzialywania Ptockiego Zespotu Miejsko-Przemystowego [Typology and regionalization of landscapes influenced by the Plock Municipal-Industrial Complex Zone], in Richling, A., Lechnio, J. (eds.), Z prob- 
lematyki funkcjonowania krajobrazów nizinnych [The issues dealing with the functioning of the lowland landscapes], Uniwersytet Warszawski, Wydział Geografii i Studiów Regionalnych [Department of Geography and Regional Studies], Warszawa, 29-54.

Richling, A., Solon, J. (1996), Ekologia krajobra$z u$ [Landscape ecology], Wydawnictwo Naukowe PWN, Warszawa.

Rutkowski, L. (2006), Szata roślinna [Vegetation], in Andrzejewski, L., Weckwerth, P., Burak S. (eds.), Tonuń $i$ jego okolice: Monografia przyrodnicza [Toruń and surrounding area: Monography of nature], UMK, Toruń, 177-189.

Sinkiewicz, M. (1998), Rozwój denudacji antropogenicznej w środkowej części Polski Północnej [Development of anthropogenic denudation in the central part of Northern Poland], Wydawnictwo UMK, Toruń.

Solon, J. (2008), Przegląd wybranych podejść do typologii krajobrazu [Review of selected views about the typology of the landscape], in Lechnio, J., Kulczyk, S., Malinowska, E., Szumacher, I. (eds.), Klasyfikacja krajobrazu: Teoria i praktyka [Classification of landscapes: Theory and practice], Problemy Ekologii Krajobrazu, 20, Wydział Geografii i Studiów Regionalnych Uniwersytetu Warszawskiego, Warszawa, 25-33.

Starkel, L. (1977), Paleogeografia holocenu [Holocene paleogeography]. Wydawnictwo Naukowe PWN, Warszawa.

Starkel, L. (1999), Rola holocenu w ewolucji środowiska i jego stratygrafia [The role and the stratigraphy of the holocene in the evolution of the environment], in Starkel, L. (ed.), Geografia Polski: Srodowisko przyrodnicze [Polish geography: The natural environment], Wydawnictwo Naukowe PWN, Warszawa, 103-105.

Weckwerth, P. (2004), Morfologia wybranych obszarów Kotliny Toruńskiej a problem jej roli w uktadzie hydrograficznym podczas górnego vistulianu [Morphology of selected areas of the Torun Basin and the role of the Torun Basin in the upper vistulian hydrographic system], Instytut Geografii UMK, Toruń, maszynopis [typescript].

Wiśniewski, E. (1976), Rozwój geomorfologiczny doliny Wisty pomiedzy Kotlina Plocka a Kotlina Toruńska [Geomorphologic development of the Vistula Valley between the Plock Basin and the Toruń Basin/, Studia Societatis Scientiarum Torunensis, Series C, 8 , 4-6, Toruń.

Wysota, W. (1994), Geneza drumlinów w środkowo-wschodniej części Pojezierza Chelmińsko-Dobrzyńskiego [Drumlin origin in the central-eastern part of the Chelmno-Dobrzyń Lakeland], Przeglad Geograficzny, 65, 3-4: 335-361.

$<$ www.eea.europa.eu/themes/landuse/clc-download > - webpage of European Environment Agency (09 Jan. 2010).

Paper first received: September 2011

In final form: December 2011 
http://rcin.org.pl 